\title{
Development and evaluation of a plantain-peanut sandwich for the Nigerian market
}

\author{
Malomo Olu, Uche E. O., Adekoyeni O. O., Alamu E. A. \\ College of Food Sciences, Bells University of Technology, Ota, Ogun State, Nigeria \\ Email address: \\ oludaremalomo1951@yahoo.com (M. Olu)
}

To cite this article:

Malomo Olu, Uche E. O., Adekoyeni O. O., Alamu E. A.. Development and Evaluation of a Plantain-Peanut Sandwich for the Nigerian Market. International Journal of Nutrition and Food Sciences. Special Issue: Optimizing Quality and Food Process Assessment.

Vol. 3, No. 6-1, 2014, pp. 50-57. doi: 10.11648/j.ijnfs.s.2014030601.17

\begin{abstract}
Protein-energy malnutrition is a common nutritional disorder in developing countries and constitutes a major public health problem in young children and elderly people. This project is aimed at evaluating the acceptability of plantainpeanut sandwich and roasted at different temperatures. A plantain-peanut sandwich consists of minced protein stuffed into a carbohydrate source made into a roll as a food product. The plantain was roasted at two different temperatures then later enriched with $5 \%, 10 \%$ and $15 \%$ peanut butter. The crude protein and crude fibre contents of the plantain samples roasted at $200^{\circ} \mathrm{C}$ and $240^{\circ} \mathrm{C}$ showed no significant difference $(\mathrm{P}>0.05)$ while the ash, fat and carbohydrate contents showed that there was a significant difference $(\mathrm{P}<0.05)$. Results of the proximate composition showed that there was significant difference $(\mathrm{P}<0.05)$ at the two different roasting temperatures of $200^{\circ} \mathrm{C}$ and $240^{\circ} \mathrm{C}$ when enriched at $5 \%, 10 \%$ and $15 \%$ levels with peanut butter. This pattern of significant increase was also observed with the amino acid profiles at the two different roasting temperature levels.
\end{abstract}

Keywords: Plantain Peanut Butter, Roasting, Sandwich, Enrichment, Amino Acid Profile

\section{Introduction}

\subsection{Plantain}

Nigeria is faced with the problem of malnutrition due to deficiency of protein and calories. The protein-calories sources of vegetable origin have been proposed as a solution to this problem. In Nigeria and many African countries, plantains (Musa paradisica) are used as an inexpensive source of calories [4]. It is an important starchy staple and commercial crop in the West and Central Africa where fifty per cent of the world's plantain crop is produced [38]. Cassava, plantain and sweet potato are among the major starchy crops which are used in many tropical countries [12]. According to FAO [18], over 2.3 million metric tons of plantains are produced in Nigeria annually. However, about 35 to $60 \%$ post-harvest losses had been reported and attributed to lack of storage facilities and inappropriate technologies for food processing.

Plantain is a popular dietary staple due to its versatility and good nutritional value. It is starchy, less sweet variety of banana that can be used either ripe or unripe; they are invaluable source of carbohydrate, comparable in nutritive value to yam or potato and are useful as a variant on the usual staple foods. It is consumed mainly in Nigeria as snacks in form of chips, boli, dodo ikire among others..

Plantains (Musa spp., AAB genome) are plants producing fruits that remain starchy at maturity [25],[34] and need processing before consumption. Plantain production in Africa is estimated at more than $50 \%$ of worldwide production [18]. The majority $(82 \%)$ of plantains in Africa are produced in the area stretching from the lowlands of Guinea and Liberia to the central basin of the Democratic Republic of Congo. West and Central Africa contribute 61 and 21\%, respectively [13]. It is estimated that about 70 million people in West and Central Africa derive more than $25 \%$ of their carbohydrates from plantains, making them one of the most important sources of food energy throughout the African lowland humid forest zone [38]..

Plantain and bananas (Musa spp.) serve as important food crops in much of Africa. Together they provide over $25 \%$ of the carbohydrate needs and $10 \%$ of the daily calorie requirements for over 70 million people on the African 
continent [14]. The annual world production of plantain and banana is estimated at 75 million tonnes [23]. In Nigeria plantain production is estimated at about 2.11 million metric tonnes in 2004 [15],[32]

Plantains are members of the banana family. They are a starchy, low in sugar variety that is cooked before serving as it is unsuitable raw. It is used in many savoury dishes somewhat like a potato would be used and is very popular in Western Africa and the Caribbean countries. It is usually fried or baked. Plantains are native to India and are grown most widely in tropical climates. Plantains are sometimes referred to as the pasta and potatoes of the Caribbean. Sold in the fresh produce section of the supermarket, they usually resemble green bananas but ripe plantains may be black in colour. This vegetable-banana can be eaten and tastes different at every stage of development. The interior colour of the fruit will remain creamy, yellowish or lightly pink. When the peel is green to yellow, the flavour of the flesh is bland and its texture is starchy. As the peel changes to brown or black, it has a sweeter flavour and more of a banana aroma but still keeps a firm shape when cooked.

The plantain averages about $65 \%$ moisture content and the banana averages about $83 \%$ moisture content. Since hydrolysis, the process by which starches are converted to sugars, acts fastest in fruit of higher moisture content it converts starches to sugars faster in bananas than it does in plantains. A banana is ready to eat when the skin is yellow whereas a plantain is not ready to eat "out of hand" until hydrolysis has progressed to the point where the skin is almost black. Plantains grow best in areas with constant warm temperatures and protection from strong winds. They have been grown in scattered locations throughout Florida since the 16 th century.

The consumption of plantain has risen tremendously in Nigeria in recent years because of the rapidly increasing urbanization and the great demand for easy and convenient foods by the non-farming urban populations. Besides being the staple for many people in more humid regions, plantain is a delicacy and favoured snack for people even in other ecologies.

\subsection{Groundnut}

Groundnut (Arachis hypogea) is a true pulse, a member of the Leguminosae family that has gained recognition as both snack and a health food. Groundnut is a small annual herb growing up to a foot above the ground. It is thought to have originated in the Central Americas and from where it spread to rest of the world through Spanish explorers. Today, the nuts are widely cultivated oil seeds and has established as prime commercial crop in China, India, African nations, and the United States of America.

Groundnut is a rich source of fat ranging from 36 to $54 \%$ [8]. Groundnuts and groundnut butter are energy rich and nutritious foods, providing a valuable supply of a wide range of vitamins, minerals and dietary fibre [22].

Groundnuts (Arachis hypogea) have various uses:-adds to good nutritional value, as soup thickener and when cooked, roasted, dried or fried serve as snacks. Sometimes, paste used as margarine or butter. More so, there are less expensive, widely distributed easily cultivated, consumed and sold by the masses.

Peanut-containing foods have high consumer acceptance because of their unique roasted peanut flavour. Peanuts are continually applied for the preparation of new and improved food products [40]. A large proportion of peanut production in the world is destined to domestic foods such as peanut butter, snack products, confections and roasting peanut products showing positive results in relation to consumer acceptance and sensory and chemical stability [[3], [20], [29],[30];[31]. The rest of the peanut production is utilized as an edible oil source of high quality [3]. Peanuts contain high percentages of oil (45-54\%) and protein [35],[20].

Due to their high oil content, peanuts are rich in energy but are susceptible to developing rancidity and off-flavors through lipid oxidation because of their composition rich in unsaturated fatty acid (approximately $80 \%$ ), with $40-50 \%$ and $30-40 \%$ of the oil being oleic and linoleic acids, respectively [19].

Groundnut, Arachis hypogea L. also known as peanut or earthnut is a native to a region in eastern South America [42]. It is grown as an annual crop principally for its edible oil and protein rich kernels seeds, borne in pods which develop and mature below the soil surface. The groundnuts, an herbaceous plant of which there are varieties, common in the United States, grow up to $30-46 \mathrm{~cm}$ high do not spread. Runner varieties, the most common in the West Africa are shorter and run along the ground for 30-60 $\mathrm{cm}$ [9]. Peanut (Arachis hypogea L.) is now grown worldwide in the tropic and temperature zones primarily as an oilseed crop [10]. Peanut seeds make important contribution to the diet in many countries. The fatty acids composition of the endogenous fats ranges from 22 to $30 \%$. And the average oil content may reach 50\% [33],[11]. .These play an important role in determining shelf life, nutrition and flavour of peanuts seeds.

Groundnut provides an inexpensive source of high quality dietary protein and oil. The vast food preparations incorporating groundnut to improve the protein level has helped in no small way in reducing malnutrition in the developing Countries [7].

Worldwide, protein deficiency is the most common form of malnutrition. In parts of Asia, Africa and Latin America, protein deficiency occurs in millions of children [36] and groundnut is an important source of protein for the people of those regions. They are rich in many important nutrients that can help the human body stay healthy and enable to combat a variety of disease and health conditions.

In Nigeria, children suffer from kwashiorkor, due to protein deficiency, whose symptoms includes reduced energy levels, reduced immune system functioning hair loss, fatigue, constipation, reduced blood pressure, mental problems, skin rashes, weight loss, diarrhoea, kwashiorkor and reduced ability to fight infectious diseases, ultimately leading to premature death. 


\section{Materials and Methods}

\subsection{Materials}

Matured unripe plantain (Musa paradisica) and peanut (Arachis hypogea) was obtained from Sango market in Ogun state and were processed in the food processing laboratory of the food science and technology laboratory of the university.

\subsection{Methods}

\subsubsection{Preparation of Boli (Roasted Plantain)}

The plantain was washed, peeled and weighed before roasting in the oven. After roasting, the boli is weighed and cooled.

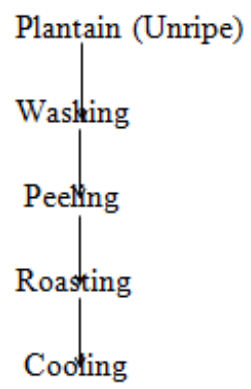

Fig 1. Flow chart for boli production

\subsubsection{Preparation of Peanut Butter}

The groundnut was washed, sorted and deshelled. The cleaned groundnut is soaked in $5 \%$ brine for 30 minutes, the brine is drained and oven dried and roasted at $80^{\circ} \mathrm{C}$ for 5 days. After roasting, the husk is removed and the groundnut is milled to produce peanut butter.

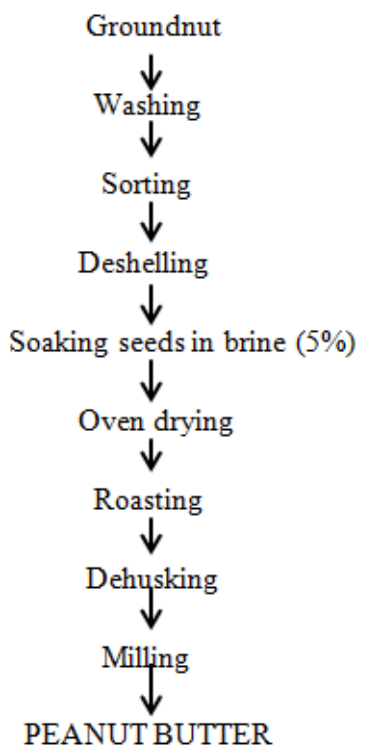

Fig 2. Flow chart of peanut butter production

\subsubsection{Plantain-Peanut Mix (Burger) Production}

The roasted plantain is weighed then $5 \%, 10 \%$ or $15 \%$ proportion of peanut butter is added to the roasted plantain. The plantain-peanut mix is then packaged and stored.

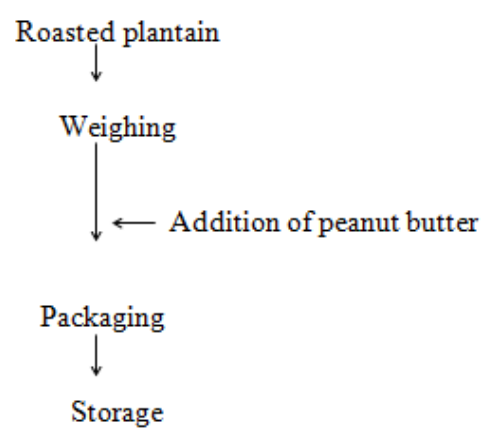

Fig 3. Flow diagram for the production of plantain-peanut mix

\subsection{Proximate Analysis}

\subsubsection{Moisture Content Determination}

The moisture content was determined using the procedure described in AOAC, [6], was used. The moisture content was determined by weighing $5 \mathrm{~g}$ of the sample into the aluminum moisture can after the weight of the can has been gotten. The sample was dried in an oven for 3 hours to a constant weight at $105^{\circ} \mathrm{C}$.

Moisture Content

$=\frac{\text { weight of can with sample }- \text { weight of empty can x100 }}{\text { Weight of sample }}$

\subsubsection{Ash Content Determination}

$3 \mathrm{~g}$ of the plantain and peanut butter samples was weighed into a pre-weighed crucible and then placed in a muffle furnace to ash at $600 \mathrm{oC}$ for 3 hours and then the ash content was calculated.

$$
\begin{aligned}
& \text { Ash content } \\
& =\frac{\text { (weight of crucible }+ \text { ash })- \text { weight of empty crucible x } 100}{\text { Weight of sample }}
\end{aligned}
$$

\subsubsection{Fat Content Determination}

Crude fat was extracted in a soxhlet extractor with petroleum ether and quantified gravimetrically. $1 \mathrm{~g}$ of sample was weighed into an extraction thimble and then stopped with grease-free cotton. Before the operation commenced, the extraction cans were dried, cooled and weighed. The thimble was placed in an extraction chamber and $80 \mathrm{ml}$ of petroleum ether was to the extraction can to extract the fat. The extraction was carried out at $135^{\circ} \mathrm{C}$ for 1 hour 15 minutes after which the fat collected in the extraction cans. The cans were dried in the oven, cooled in a desiccator and the weights were taken.

$$
\begin{aligned}
& \text { Crude fat } \\
& =\frac{\text { (weight of can }+ \text { fat })- \text { weight of empty can } \times 100}{\text { Weight of sample }}
\end{aligned}
$$

\subsubsection{Crude Protein}

The protein content was determined using a Foss Tecator TM protein digester and KJECTEC 2200 distillation apparatus (Kjedahl method) according to the procedure of AOAC, [6]. 
Concentrated $\mathrm{H}_{2} \mathrm{SO}_{4}$ and 2 tablets of catalyst were put into a kjedahl digestion flask containing $5 \mathrm{~g}$ of the sample. The flask was placed in the digester in a fume cupboard and switched on and digestion was done for 45 minutes to obtain a clear colorless solution. The digestion was distilled with $4 \%$ boric acid, $20 \%$ sodium hydroxide solutions were automatically metered into it in the KJECTEC 2200 distillation equipment until distillation was complete. The distillate was then filtered with $0.1 \mathrm{M} \mathrm{HCl}$ until a violet color formation indicating the end point. A blank was run under the same condition as with the sample. Total nitrogen content was then calculated according to the formula:

$$
\begin{aligned}
& \text { Crude protein } \\
& =\frac{(\text { titre }(\text { of sample })-\text { blank }) \times 0.01 \times 14.07 \times 6.25}{10 \times \text { weight of sample }}
\end{aligned}
$$

\subsubsection{Crude Fibre}

$2 \mathrm{~g}$ of the sample was transferred into 1 litre conical flask. $100 \mathrm{ml}$ of sulfuric acid $(0.255 \mathrm{M})$ was heated to boiling and then introduced into the conical flask containing the sample. The contents were then boiled for 30minutes and ensuring that the level of acid was maintained by addition of distilled water. After 30 minutes, the contents were then filtered through a muslin cloth held in a funnel. The residue was then transferred into a conical flask. $100 \mathrm{ml}$ of sodium hydroxide $(0.313 \mathrm{M})$ was then brought to boil and then introduced into the conical flask containing the sample. The contents were boiled for 30 minutes and ensuring that the level of the acid was maintained by the addition of distilled water. After 30 minutes, the contents were filtered through a muslin cloth held in a funnel. The residue was rinsed thoroughly into an already dried crucible and ashed at $600^{\circ} \mathrm{c}$.

Crude fibre

$=\frac{\text { final weight of crucible }- \text { initial weight of crucible } \times 100}{\text { Weight of sample }}$

\subsection{Mineral Content Composition}

The dry ashing procedure was used for mineral content determination. $5 \mathrm{~g}$ of each sample were accurately weighed into porcelain crucibles and pre-ashed. The pre-ashed samples were thereafter ashed in the muffle furnace at $600^{\circ} \mathrm{C}$ till the ash was white for about 2 hours. After ashing, the crucibles were transferred into the desiccator to cool and then reweighed. Each sample was quantitatively transferred into volumetric flasks by carefully washing the crucibles having the samples with $30 \mathrm{ml}$ of $0.1 \mathrm{M} \mathrm{H}_{2} \mathrm{SO}_{4}$ through a filter paper.

The solutions were diluted to volume with deionized water and were used for individual mineral determination using the appropriate standards and blank. The content of the minerals; magnesium, iron and copper, were determined with the Atomic Absorption Spectrophotometer (Buck Scientific, Model 210).

The percentage mineral content was calculated as follows: Calculation:
\%Mineral Element Concentration

$$
=\frac{\text { meter reading } \mathrm{x} \text { slope } \mathrm{x} \text { dilution factor }}{1000}
$$

\subsection{Amino Acid Profile}

The analysis of the amino acids was done using WATERS 616/626 LC High Performance Liquid Chromatogaphy (HPLC) instrument.

Amino acid analysis is a method of estimating the concentration of each individual amino acid present in a given protein or peptide samples.

The sample preparation and determination were carried out in the following stages;

1. Hydrolysis

2. Derivatisation

3. Separation of the derivatised amino acids

4. Data processing /interpretation and calculations of the final results.

\subsubsection{Step (1) Hydrolysis of the Samples}

$0.5 \mathrm{~g}$ of the sample was weighed into sterile furnaces hydrolysis tube, $5 \mathrm{nmols}$ norlecucine was added to the sample and then dried under a vacuum.

The tube was again placed in a vial containing $10.05 \mathrm{~N}$ HCL with a small quantity of phenol, thereby hydrolyzing the protein by the HCL vapours under vacuum. This stage of hydrolysis of the samples lasted for between 20-30 hours at $108^{\circ} \mathrm{c}$ grade, containing ethylene diamine tetra acetic acid (EDTA). The EDTA chelates HPLC amino acids analyzer bottles for further analytical operations.

Step (2) Derivatisation; the hydrolyzed samples were derivatised automatically using the water 616/626 HPLC by reacting the five amino acid, under basic situations with phenylisothiocyanate (i.e. PITC) to get phenylthiocarbamyl (PTC) amino acid derivatives. The duration for this is 45 minutes per sample, as calibrated on the instrument.

These standards $(0.0,0.5,1.0,1.5,2.0 \mathrm{umol})$ were used to generate a calibration file that was to determine the amino acids content of the samples. After the derivatisation, a methanol solution $(1.5 \mathrm{~N})$ containing the PTC-amino acid was transferred to a narrow bore waters $616 / 626$ HPLC system for separation.

\subsubsection{Step (3) the HPLC Separation and Quantization}

The separation and quantization of the PTC-amino acids were done on a reverse phase (18 silica column and the PTC chromo phone were automatically and digitally detected at the wavelength of $245 \mathrm{~nm}$.

The elution of the whole amino acids in the samples took 30minutes. The buffer system used for separation was $140 \mathrm{~mm}$ sodium acetate $\mathrm{pH} 5.50$ as buffer A and $80 \%$ acetonitrile as buffer B.

The program was run using a gradient of buffer $A$ and buffer B concentration and ending with a $55 \%$ buffer $\mathrm{B}$ concentration at the end of the gradient. 


\subsubsection{Step (4) Data Interpretation and Calculations}

The intensity of the chromatography peaks areas were automatically and digitally identified and quantified using a Dionex chrome Leon data analysis system which is attached to the waters 616/626 HPLC system.

The calibration curve or file prepared from the average values of the retention times (in minutes) and areas (in $\mathrm{Au}$ ) at the amino acids in 5 standards runs was used.

Since a known amount of each amino acid in the loaded into the HPLC, a response factor $(\mathrm{Au} / \mathrm{pmol})$ was calculated by the software that was interphase with the HPLC. This response factor was used to calculate the amount of each of the amino acid (in pmols) in the sample and displayed on the system digitally. The amount of each amino acid in the sample is finally calculated by the software by dividing the intensity of the intensity of the peak area of each (corrected for the differing molar absorptive of the various amino acids) by the internal standard (i.e. Pierce) in the chromatogram and multiplying this by the total amount of internal standard added to the original sample.

After the Pico mole by the intensity of the height of each amino acid has been ascertained by the software, the data, the digital chromatographic software extrapolate back to 5 nmoles of the internal standard (Norlecucine), and displays for the total amount that was pipetted into the hydrolysis tube at the beginning of the analysis as below;

Calculations;

$\mathrm{mg} / \mathrm{ml}($ in Extract $)=$ Dilution factor $\mathrm{x}$ peak height intensity

$\mathrm{mg} / \mathrm{ml}$ (in samples) $=\mathrm{ug} / \mathrm{ml}$ in extract $\mathrm{x}$ sample volume/wt of sample.

\section{Results and Discussion}

\subsection{Proximate Composition of Peanut Butter and Plantain Roasted at Different Temperatures}

The results obtained from the proximate analysis in Table 1 showed a significant difference $(\mathrm{P}>0.05)$ between the ash, fat and carbohydrate content of the plantains roasted at $200^{\circ} \mathrm{C}$ and $240^{\circ} \mathrm{C}$ and no significant difference $(\mathrm{P}<0.05)$ between the protein and crude fibre content. However, the difference between the peanut butter in terms of protein content, fat and carbohydrate content and the roasted plantain at different temperatures of roasting were highly significant even at $1 \%$ level $(\mathrm{P}<0.01)$. The protein component of peanut butter at $27.3 \%$ on dry weight basis as compared with the protein components of plantain roasted at $200^{\circ} \mathrm{C}$ and $240^{\circ} \mathrm{C}$ which is $2.37 \%$ and $2.41 \%$ respectively. Hence, that is the reason behind the enhancement of the plantain to produce "plantainpeanut burger or plantain-peanut sandwich" which is described as protein source (peanut butter) minced and stuffed into a carbohydrate source made into a roll as a food product. There was also a significant difference $(\mathrm{P}<0.05)$ in the crude fibre and carbohydrate content between the peanut butter and plantain samples roasted at $200^{\circ} \mathrm{C}$ and $240^{\circ} \mathrm{C}$.

Table 1. Proximate composition of peanut butter and plantain roasted at different temperatures on dry weight basis

\begin{tabular}{llll}
\hline & $\begin{array}{l}\text { Peanut butter } \\
\mathbf{( \% )}\end{array}$ & $\begin{array}{l}\mathbf{2 0 0}^{\mathbf{0}} \mathbf{C} \text { plantain } \\
\mathbf{( \% )}\end{array}$ & $\begin{array}{l}\mathbf{2 4 0}^{\mathbf{0}} \mathbf{C} \\
\text { plantain(\%) }^{\text {\% }}\end{array}$ \\
\hline Ash & $2.78 \pm 0.04^{\mathrm{a}}$ & $3.01 \pm 0.01^{\mathrm{b}}$ & $3.14 \pm 0.02^{\mathrm{c}}$ \\
crude fibre & $3.36 \pm 0.01^{\mathrm{b}}$ & $2.56 \pm 0.01^{\mathrm{a}}$ & $2.59 \pm 0.05^{\mathrm{a}}$ \\
Fat & $42.9 \pm 0.05^{\mathrm{c}}$ & $2.19 \pm 0.02^{\mathrm{b}}$ & $1.9 \pm 0.13^{\mathrm{a}}$ \\
crude protein & $27.3 \pm 0.10^{\mathrm{b}}$ & $2.37 \pm 0.01^{\mathrm{a}}$ & $2.41 \pm 0.01^{\mathrm{a}}$ \\
carbohydrates & $23.55 \pm 0.10^{\mathrm{a}}$ & $89.85 \pm 0.07^{\mathrm{b}}$ & $89.94 \pm 0.09^{\mathrm{c}}$ \\
\hline
\end{tabular}

Values within the same row with different superscript letters are significantly different from each other $(\mathrm{p}<0.05)$.

LEGEND:

$200^{\circ} \mathrm{C}$ P: PLANTAIN ROASTED AT $200^{\circ} \mathrm{C}$,

$240^{\circ} \mathrm{C}$ P: PLANTAIN ROASTED AT $240^{\circ} \mathrm{C}$

5\% PB: ENRICHMENT WITH 5\% PEANUT BUTTER

10\% PB: ENRICHMENT WITH 10\% PEANUT BUTTER

15\% PB: ENRICHMENT WITH 15\% PEANUT BUTTER

\subsection{Proximate Composition of Roasted Plantain at Different Temperatures Enriched with Different Proportions of Peanut Butter}

Table 2. Proximate composition of roasted plantain at different temperatures enriched with diferent proportions of peanut butter on dry weight basis.

\begin{tabular}{|c|c|c|c|c|c|c|}
\hline & $200^{\circ} \mathrm{C} P+5 \% \mathrm{~PB}$ & $200^{\circ} \mathrm{C} P+10 \% \mathrm{~PB}$ & $200^{\circ} \mathrm{C} P+15 \% \mathrm{~PB}$ & $240^{\circ} \mathrm{C} P+5 \% \mathrm{~PB}$ & $240^{\circ} \mathrm{C} P+10 \% \mathrm{~PB}$ & $240^{\circ} \mathrm{C} P+15 \% \mathrm{~PB}$ \\
\hline Ash & $3.91 \pm 0.05^{\mathrm{d}}$ & $3.56 \pm 0.01^{\mathrm{d}}$ & $4.72 \pm 0.02^{\mathrm{e}}$ & $1.84 \pm 0.02^{\mathrm{a}}$ & $3.08 \pm 0.02^{\mathrm{c}}$ & $3.02 \pm 0.02^{\mathrm{b}}$ \\
\hline crude fibre & $4.56 \pm 0.02^{\mathrm{d}}$ & $3.81 \pm 0.02^{\mathrm{c}}$ & $3.43 \pm 0.02^{b}$ & $3.98 \pm 0.01^{\mathrm{c}}$ & $3.57 \pm 0.01^{\mathrm{b}}$ & $3.19 \pm 0.02^{\mathrm{a}}$ \\
\hline Fat & $20.44 \pm 0.03^{\mathrm{a}}$ & $24.92 \pm 0.08^{\mathrm{c}}$ & $29.57 \pm 0.08^{\mathrm{e}}$ & $20.64 \pm 0.50^{b}$ & $26.47 \pm 0.55^{\mathrm{d}}$ & $30.30 \pm 0.76^{\mathrm{f}}$ \\
\hline crude protein & $4.77 \pm 0.29^{\mathrm{a}}$ & $6.39 \pm 0.06^{b}$ & $7.99 \pm 0.10^{c}$ & $5.01 \pm 0.05^{\mathrm{a}}$ & $6.70 \pm 0.09^{b}$ & $8.09 \pm 0.04^{c}$ \\
\hline Carbohydrate & $66.30 \pm 0.35^{\mathrm{b}}$ & $61.30 \pm 0.33^{c}$ & $54.27 \pm 0.31^{\mathrm{a}}$ & $68.50 \pm 0.36^{\mathrm{d}}$ & $60.17 \pm 0.50^{\mathrm{c}}$ & $55.38 \pm 0.33^{c}$ \\
\hline
\end{tabular}

Values within the same row with different superscript letters are significantly different from each other $(\mathrm{p}<0.05)$

LEGEND:

$200^{\circ} \mathrm{C}$ P: PLANTAIN ROASTED AT $200^{\circ} \mathrm{C}$

$240^{\circ} \mathrm{C}$ P: PLANTAIN ROASTED AT $240^{\circ} \mathrm{C}$

5\% PB: ENRICHMENT WITH 5\% PEANUT BUTTER

10\% PB: ENRICHMENT WITH 10\% PEANUT BUTTER

15\% PB: ENRICHMENT WITH 15\% PEANUT BUTTER

The result in Table 2 showed the enhanced plantain burger roasted at different temperatures of $200^{\circ} \mathrm{C}$ and $240^{\circ} \mathrm{C}$ showed appreciable increase in protein and fat components as the level of enhancement increases as compared to Abioye et.al.(2011) where the protein and fat contents increased with increasing level of soy flour substitution indicating nutrients enhancement with soy flour substitution ranging from $2.54 \%$ and $0.45 \%$ ( $0 \%$ soy flour substitution) to $8.40 \%$ and $7.05 \%$ 
(40\% soy flour substitution) respectively, [1]. The significant increase in the fat and protein content is obviously due to the significant quantity of protein and fat in peanut butter. There is a significant decrease $(\mathrm{P}<0.05)$ in the carbohydrate content as the content of the peanut butter increases which is similar to a research by Adelakun et.al [2], the physical, compositional and sensory characteristics of soybean substitution in the production of kokoro, the protein and fat contents increased while the carbohydrate content decreased as the proportion of soybean flour mixture was increased. There is a significant increase in the ash content of the roasted plantain at $200^{\circ} \mathrm{C}$ and $240^{\circ} \mathrm{C}$ as the proportion of the peanut butter increased.

\subsection{Essential Amino Acid Profile of Peanut Butter, Roasted Plantain at Different Temperatures and at Different Enrichment Levels}

The result in Table 3 shows the amino acid profile of peanut butter, and plantain roasted at $200^{\circ} \mathrm{C}$ and $240^{\circ} \mathrm{C}$ respectively. For peanut butter, threonine had the highest percentage among the essential amino acid having 3.2\%, this amino acid is needed to create other amino acids that aid the production of collagen and it is also important for antibody production (Travis, 2014) followed by lysine $(2.37 \%)$.in the plantain samples roasted at $200^{\circ} \mathrm{C}$ and $240^{\circ} \mathrm{C}$, there was a decrease in most of the essential amino acids except leucine and arginine. Lysine is the most vulnerable to stress of all the amino acids, because of the epsilon group which could easily be knocked off during processing [24].

The result in Table 4 shows the essential amino acid profile of plantain roasted at $200^{\circ} \mathrm{C}$ enriched with different $5 \%, 10 \%$ and $15 \%$ peanut butter. There is an appreciable increase in the percentage of the essential amino acids as the proportion of peanut butter increases. Also in the substitution of soy bean with poundo yam, the amino acid of poundo yam increased with increasing enrichment levels [12].

Table 3. Essential amino acid profile of roasted plantain at different temperatures.

\begin{tabular}{llll}
\hline AMINO ACIDS & Peanut butter & $\mathbf{2 0 0}^{\mathbf{0}}$ plantain & $\mathbf{2 4 0}^{\mathbf{0}}$ plantain \\
\hline Threonine & 3.20 & 2.03 & 1.85 \\
Leucine & 0.84 & 0.06 & 0.49 \\
Isoleucine & 0.41 & 1.06 & 0.90 \\
Lysine & 2.37 & 1.00 & 0.77 \\
Methionine & 0.77 & 0.49 & 0.45 \\
Phenylalanine & 0.85 & 1.46 & 1.10 \\
Tyrosine & 1.39 & 1.45 & 0.70 \\
Valine & 0.28 & 0.45 & 0.10 \\
Arginine & 0.74 & 0.13 & 0.99 \\
Histidine & 1.07 & 1.02 & 0.44 \\
\hline
\end{tabular}

LEGEND:

$200^{\circ} \mathrm{C}$ P: PLANTAIN ROASTED AT $200^{\circ} \mathrm{C}$

$240^{\circ} \mathrm{C}$ P: PLANTAIN ROASTED AT $240^{\circ} \mathrm{C}$

5\% PB: ENRICHMENT WITH 5\% PEANUT BUTTER

10\% PB: ENRICHMENT WITH 10\% PEANUT BUTTER

15\% PB: ENRICHMENT WITH 15\% PEANUT BUTTER
Table 4. Essential amino acid profile of $200^{\circ} \mathrm{c}$ roasted plantain enriched with different proportions of peanut butter.

\begin{tabular}{llll}
\hline AMINO ACID & $\mathbf{2 0 0}^{\mathbf{0}} \mathbf{C} \mathbf{P}+\mathbf{5 \%} \mathbf{P B}$ & $\begin{array}{l}\mathbf{2 0 0}^{\mathbf{0}} \mathbf{C} \mathbf{P}+\mathbf{1 0} \% \\
\mathbf{P B}\end{array}$ & $\begin{array}{l}\mathbf{2 0 0}^{\mathbf{0}} \mathbf{C}+\mathbf{1 5} \% \\
\mathbf{P B}\end{array}$ \\
\hline Threonine & 2.06 & 2.14 & 2.20 \\
Leucine & 0.09 & 0.13 & 0.18 \\
Isoleucine & 0.95 & 0.97 & 1.01 \\
Lysine & 1.06 & 1.12 & 1.19 \\
Methionine & 0.51 & 0.52 & 0.53 \\
Phenylalanine & 1.34 & 1.35 & 1.32 \\
Tyrosine & 0.48 & 0.52 & 0.58 \\
Valine & 0.13 & 0.14 & 0.15 \\
Arginine & 0.98 & 0.99 & 1.01 \\
Histidine & 0.33 & 0.37 & 0.41 \\
\hline
\end{tabular}

LEGEND:

$200^{\circ} \mathrm{C}$ P: PLANTAIN ROASTED AT $200^{\circ} \mathrm{C}$

$240^{\circ} \mathrm{C}$ P: PLANTAIN ROASTED AT $240^{\circ} \mathrm{C}$

5\% PB: ENRICHMENT WITH 5\% PEANUT BUTTER

10\% PB: ENRICHMENT WITH 10\% PEANUT BUTTER

15\% PB: ENRICHMENT WITH 15\% PEANUT BUTTER

Table 5. Essential amino acid profile of $240^{\circ} \mathrm{c}$ roasted plantain enriched with different proportions of peanut butter.

\begin{tabular}{llll}
\hline AMINO ACID & $\mathbf{2 4 0}^{\mathbf{0}} \mathbf{C} \mathbf{P}+\mathbf{5 \%}$ & $\mathbf{2 4 0}^{\mathbf{}} \mathbf{C} \mathbf{P}+$ & $\mathbf{2 4 0}^{\mathbf{C}} \mathbf{C} \mathbf{P}+$ \\
$\mathbf{1 0 \%}$ & $\mathbf{P B}$ & $\mathbf{1 0} \%$ & $\mathbf{P B}$ \\
\hline Threonine & 2.00 & 2.03 & 2.11 \\
Leucine & 0.53 & 0.55 & 0.89 \\
Isoleucine & 0.82 & 0.85 & 0.87 \\
Lysine & 0.85 & 0.93 & 1.00 \\
Methionine & 0.46 & 0.47 & 0.49 \\
Phenylalanine & 1.06 & 1.07 & 1.08 \\
Tyrosine & 0.40 & 0.45 & 0.50 \\
Valine & 0.79 & 0.81 & 0.84 \\
Arginine & 0.93 & 0.94 & 0.97 \\
Histidine & 0.47 & 0.49 & 0.53 \\
\hline
\end{tabular}

LEGEND:

$200^{\circ} \mathrm{C}$ P: PLANTAIN ROASTED AT $200^{\circ} \mathrm{C}$

$240^{\circ} \mathrm{C}$ P: PLANTAIN ROASTED AT $240^{\circ} \mathrm{C}$

5\% PB: ENRICHMENT WITH 5\% PEANUT BUTTER

10\% PB: ENRICHMENT WITH 10\% PEANUT BUTTER

15\% PB: ENRICHMENT WITH 15\% PEANUT BUTTER

The result in Table 5 shows the essential amino acid profile of plantain roasted at $240^{\circ} \mathrm{C}$ enriched with $5 \%, 10 \%$ and $15 \%$ peanut butter, there is also an increase in the percentage of essential amino acids as the proportion of peanut butter increases.

\subsection{Mineral Content Of Peanut Butter and Plantain Roasted at Different Temperatures}

The mineral content of peanut butter and plantain roasted at $200^{\circ} \mathrm{C}$ and $240^{\circ} \mathrm{C}$ is shown in table 6 .

The result showed a significant difference $(\mathrm{P}<0.05)$ between peanut butter and plantain roasted at $200^{\circ} \mathrm{C}$ and $240^{\circ} \mathrm{C}$ in the magnesium content, the magnesium content of peanut butter is higher than the magnesium content in the plantain roasted at $200^{\circ} \mathrm{C}$ and $240^{\circ} \mathrm{C}$. Also in the iron and copper content of peanut butter, $200^{\circ} \mathrm{C}$ roasted plantain and $240^{\circ} \mathrm{C}$ roasted plantain.

Table 7 , showed a significant difference $(\mathrm{P}<0.05)$ in the magnesium, iron and copper content of $200^{\circ} \mathrm{C}$ roasted 
plantain enriched with $5 \%, 10 \%$ and $15 \%$ proportions of peanut butter.

Similarly following same pattern as in table 8 , there was also a significant difference $(\mathrm{P}<0.05)$ in the magnesium, iron and copper content of $240^{\circ} \mathrm{C}$ roasted plantain enriched with $5 \%, 10 \%$ and $15 \%$ proportions of peanut butter.

As already reported that fortification with soy flour was advantageous due to the increased nutritional value (higher mineral and protein content) (Morteza et.al, 2008). One would also expect that fortification or enrichment with peanut butter or any plant protein would follow similar trend.

\section{Conclusion}

Results from this study indicated that the peanut butter used in enriching the roasted plantain was able to increase the protein content as well as other proximate compositions except for the carbohydrate in the various combinations. Also the amino acid profile of the peanut burger increased with enrichment levels. The overall acceptability of the plantain roasted at $240^{\circ} \mathrm{C}$ enriched with $15 \%$ peanut butter received the highest rating.

In conclusion, the addition of peanut butter at 5\%, 10\% and $15 \%$ levels resulted in notable increase in protein content which could be a very good nutritional advantage to Nigerians as a result of the expensive cost of animal protein. The addition of peanut butter will have little or no effect on the final market price because of the ease of availability of peanut in the market.

Table 6. Mineral content of peanut butter and roasted plantain at different temperatures.

\begin{tabular}{llll}
\hline Sample & $\begin{array}{l}\text { Magnesium } \\
\mathbf{m g} / \mathbf{1 0 0 g}\end{array}$ & $\begin{array}{l}\text { iron } \\
\mathbf{m g} / \mathbf{1 0 0 g}\end{array}$ & $\begin{array}{l}\text { copper } \\
\mathbf{m g} / \mathbf{1 0 0 g}\end{array}$ \\
\hline Peanut Butter & $101.00^{\mathrm{b}}$ & $2.40^{\mathrm{b}}$ & $0.71^{\mathrm{a}}$ \\
$200^{\circ} \mathrm{C}$ plantain & $47.20^{\mathrm{a}}$ & $2.19^{\mathrm{a}}$ & $1.40^{\mathrm{b}}$ \\
$240^{\circ} \mathrm{C}$ plantain & $47.20^{\mathrm{a}}$ & $2.22^{\mathrm{a}}$ & $1.50^{\mathrm{b}}$ \\
\hline
\end{tabular}

Table 7. Mineral content of roasted plantain at $200^{\circ} \mathrm{C}$ enriched with different proportions of peanut butter.

\begin{tabular}{llll}
\hline Samples & $\begin{array}{l}\text { Magnesium } \\
\mathbf{m g} / \mathbf{1 0 0 g}\end{array}$ & $\begin{array}{l}\text { iron } \\
\mathbf{m g} / \mathbf{1 0 0 g}\end{array}$ & $\begin{array}{l}\text { copper } \\
\mathbf{m g} / \mathbf{1 0 0 g}\end{array}$ \\
\hline $200^{\circ} \mathrm{CP}+5 \% \mathrm{~PB}$ & $47.55^{\mathrm{a}}$ & $2.19^{\mathrm{a}}$ & $1.41^{\mathrm{a}}$ \\
$200^{\circ} \mathrm{CP}+10 \% \mathrm{~PB}$ & $48.09^{\mathrm{b}}$ & $2.25^{\mathrm{b}}$ & $1.45^{\mathrm{b}}$ \\
$200^{\circ} \mathrm{CP}+15 \% \mathrm{~PB}$ & $48.85^{\mathrm{c}}$ & $2.55^{\mathrm{c}}$ & $1.51^{\mathrm{c}}$ \\
\hline
\end{tabular}

Table 8. Mineral content of roasted plantain at $240^{\circ} \mathrm{c}$ enriched with different proportions of peanut butter.

\begin{tabular}{llll}
\hline Samples & $\begin{array}{l}\text { Magnesium } \\
\mathbf{m g} / \mathbf{1 0 0 g}\end{array}$ & $\begin{array}{l}\text { iron } \\
\mathbf{m g} / \mathbf{1 0 0 g}\end{array}$ & $\begin{array}{l}\text { copper } \\
\mathbf{m g} / \mathbf{1 0 0 g}\end{array}$ \\
\hline $240^{\circ} \mathrm{CP}+5 \% \mathrm{~PB}$ & $47.23^{\mathrm{a}}$ & $2.24^{\mathrm{a}}$ & $1.46^{\mathrm{a}}$ \\
$240^{\circ} \mathrm{CP}+10 \% \mathrm{~PB}$ & $47.53^{\mathrm{b}}$ & $2.29^{\mathrm{b}}$ & $1.5^{\mathrm{b}}$ \\
$240^{\circ} \mathrm{CP}+15 \% \mathrm{~PB}$ & $48.35^{\mathrm{c}}$ & $2.7^{\mathrm{c}}$ & $1.57^{\mathrm{c}}$ \\
\hline
\end{tabular}

LEGEND: $200^{\circ} \mathrm{C}$ P: PLANTAIN ROASTED AT $200^{\circ} \mathrm{C}$,

$240^{\circ} \mathrm{C}$ P: PLANTAIN ROASTED AT $240^{\circ} \mathrm{C}$

5\% PB: ENRICHMENT WITH 5\% PEANUT BUTTER

10\% PB: ENRICHMENT WITH 10\% PEANUT BUTTER

15\% PB: ENRICHMENT WITH 15\% PEANUT BUTTER

\section{References}

[1] Abioye,V.F. B. I. O. Ade-Omowaye, G. O. Babarinde and M. K. Adesigbin. (2011). Chemical, physico-chemical and sensory properties of soy-plantain flour. African Journal of Food Science Vol. 5(4), pp. 176 - 180, April 2011.

[2] Adelakun, O. E., Adejuyitan,J. A., Olajide, J. O.,\& Alabi, B. K (2005), Effect of Soybean Substitution on some Physical, Compositional and Sensory Properties of Kokoro (a local maize snack). European Food Research and Technology, 220, 79- 82

[3] Ahmed EM and CT Young, (1982) Composition, quality, and flavor of peanuts. In: Pattee HE and CT Young (eds). Peanut Science and technology. Yoakum, Texas: AM Peanut Res. Edu. Soc. 1982; 655-688.

[4] Akubor PI, Ojih S A (2009). Effect of ripening of plantain fruit on the chemical and sensory qualities of fayaba-a traditional plantain: maize snack Niger. J. Nutr. Sci. 30 (2):116-122.

[5] Akubor PI (2003). Functional properties and performance of cowpea/ plantain/ wheat flour blends in biscuit. Plant Foods Hum. Nutr. 58:1-8

[6] AOAC (1990). Official Method of Analysis of the Association of Official Analytical Chemists, 15th ed; AOAC Artington, Virginia.

[7] Asibuo,J.Y, Akromah, R,Safo-Kantanka,O.Osei,Adu-Dapaah, Hanskofi,O.S and Agyeman,A. (2008).Chemical Composition of Groundnut,Arachis hypogaea(L)landraces. African Journal of Biotechnology. Vol, 7(13),pp: 2203-2208. Website http://www.academicjournais.org/AJB

[8] Asibu, J.Y., R. Akromah, H. K. Adu-Dapaah and O. SafoKantanka. (2008). Evaluation of nutritional quality of groundnut (Arachis hypogaea L.) from Ghana. AJFAND, 8(2): 133-150.

[9] Asiedu, J.J., (1992). Processing Tropical crops A technological Approach. The Macmillan Press Publication Ltd second Edition, pp: 43-84, 124-145,167-788.

[10] Bansal,U.K,D.R.Satija and K.L.Ahula (1993).Oil Composition of diverse groundnut(Arachis hypogea.L) genotypes relation to different environments.J.Sci. Food Agric.63:17-19.

[11] Derise, N.L., H.A. Lau, S.J. Ritchey and E.W. Murphy, (1974) Yield, proximate composition and mineral elemental content of three cultivars of raw and roasted peanuts. J. Food Sci., 39: 264-266.

[12] FAO (1990). Food Agriculture Organisation (FAO) 1990. Annuaire de la production mondiate (Annual Book of the World Production). Roma, Italy

[13] FAO(1999). Banana: Plantain Post-harvest Operations.

[14] FAO (2004). Food and Agriculture Organisation, Statistics series No. 95. Food and Agriculture Organisation of the United Nations, Rome, 2004.

[15] FAO. 2005

http//apps.fao.org/page/collection?subset=agriculture 
[16] FAO. 2005.

http//apps.fao.org/page/collection?subset=agriculture

[17] FAO. 2004

http//apps.fao.org/page/collection?subset=agriculture

[18] FAO (1990) FAO Corporate Document Repository.

[19] Frankel EN. (2005).Lipid Oxidation, 2nd ed, The Oily Press. Bridgewater, England, pp.1-470.

[20] Grosso NR, Nepote V, Giannuzzo N, Guzm·n CA. (2002).ComposiciUn porcentual de $\cdot$ cidos grasos y de esteroles de algunos genotipos de especies silvestres de manÌ. Anales de la AsociaciÛn Quİmica Argentina (Journal of the Argentine Chemical Society) 90 (4/6),45-53.

[21] Grosso NR, Resurreccion AVA. (2002).Predicting consumer acceptance ratings of cracker-coated and roasted peanuts from descriptive analysis and hexanal measurements. J.Food Sci.67, $1530-1537$.

[22] Jennette, H. (2003). The beneficial role of peanuts in the dietPart 2. Nutr. Food Sci., 33: 56-64.

[23] John, P. and J. Marchal, (1995). Ripening and biochemistry of the fruit. In: Gowen, S.R. (ed.). Bananas and Plantains, Chapman and Hall, London, UK..

[24] Malomo Olu, Ogunmoyela O. A. B., Adekoyeni O. O., Jimoh O., Oluwajoba S.O, Sobanwa M. O., (2012) "Rheological and Functional Properties of Soy-Poundo Yam Flour", International Journal of Food Science and Nutrition Engineering, Vol. 2 No. 6, 2012, pp. 101-107.

[25] Marriott J, Lancaster PA (1983). Bananas and Plantains. In: Handbook of Tropical Foods. Harvey Jr. TC (Ed), Marcel Dekker, Inc. pp. 85-142.

[26] Maziya-Dixon B., Akinyele I.O., Oguntona E.B. , Nokoe S., Sanusi R.A., and Harris E. Nigeria Food Consumption and Survey 2001-2003 summary.

[27] Morelle, S. (1997). Production et utilisation de farine de plantains et bananes à cuire. pp. 22. Rapport de stage effectué au CRBP de Njombé au Cameroun du 1er Juillet au 29 Août 1997.

[28] Morteza Mashayekh, Mohammad Reza Mahmoodi and Mohammad Hasan Entezari (2008) Effect of fortification of defatted soy flour on sensory and rheological properties of wheat bread. International Journal of Food Science and Technology,2008,43:1693-1698

[29] Nepote V, Mestrallet MG, Accietto RH, Galizzi M, Grosso NR.(2006a).Chemical and sensory stability of roasted higholeic peanuts from Argentina. J.Sci.Food Agric.86, 944-952.

[30] Nepote V, Mestrallet MG, Grosso NR. (2006b).Oxidative stability in fried-salted peanuts elaborated with high-oleic and regular peanut from Argentina. I.J.Food Sci.and Tech.41, 900909.

[31] Nepote V, Mestrallet MG, Olmedo RH, Ryan LC, Conci S,Grosso NR.(2008).Chemical Composition and Sensory Analysis of Roasted Peanuts Coated with Prickly Pear and Algarrobo Pod Syrups. Grasas y Aceites 59, 174-181.

[32] Ogazi, P.O., (1996). Plantain: production, processing and utilisation. Paman Associates Ltd., Imo State,Nigeria, pp: 305.

[33] Pancholly, S.K., A.S. Deshpande and S. Krall, (1978).Amino acids, oil and protein content of some selected peanuts cultivars proc. Am. peanut. Res.Educ. Soc.,10:30-37.

[34] Robinson, J.C., (1996). Bananas and Plantains. CAB. International, Wallingford, UK., pp: 238.

[35] Savage GP, Keenan JI. (1994).The composition and nutritive value of Groundnut kernels, in Smart J (Ed.).The Groundnut Crop, Chapman and Hall. London.UK, pp.173-213.

[36] Sommer, A., (1989). New imperatives for an old vitamin (A). J. Nutr., 119: 96-100.

[37] Stover, R.H and N.W. Simmonds. (1987). Bananas. 3rd ed. Wiley. New York, USA: 97-103.

[38] Swennen, R. (1990). Plantain Cultivation under West African Conditions. A Reference Manual. Amarin Printing Group Co., Bangkok.

[39] Woodroof, J.G., (1983). Peanuts, production processing, products 3rd edition AVI publising company, Inc.Westport Connecticut.

[40] Weiss, E.A., (1983). “Oilseed Crops" First edition, pp: 100117.

[41] Weiss, T.J., (1983). Physical and chemical properties of fats and oils. In food oils and their uses. AVI publ.co. Inc. Westport. com. USA. Second edition, pp: 25-31, 44-84. 